\title{
Combined effects of C225 and 125-iodine seed radiation on colorectal cancer cells
}

\author{
Jingjia Liu', Hao Wang ${ }^{1}$, Ang Qu', Jinna Li ${ }^{1}$, Yong Zhao ${ }^{2}$ and Junjie Wang ${ }^{1 *}$
}

\begin{abstract}
Background: To characterize the effect of combined treatment of the anti-epidermal growth factor receptor (EGFR) monoclonal antibody C225 and 125-iodine $\left({ }^{125} \mathrm{I}\right)$ seed radiation in human colorectal cancer.

Methods: We treated LS180 cells with ${ }^{125}$ I continuous low dose rate radiation in the presence and absence of 100 nM C225. The clonogenic capacity, cellular proliferation, cell cycle distribution, apoptosis, and molecular pathways of the cells following the treatments were analyzed in vitro.

Results: The sensitizer enhancement ratio of C225 was approximately 1.4. Treatment with C225 and radiation alone produced significant inhibition of cell growth, but combination therapy produced greater inhibition than either treatment administered alone. C225 increased the radiation-induced apoptosis and the fraction of $\mathrm{Y}-\mathrm{H} 2 \mathrm{AX}$ foci positive cells at $48 \mathrm{~h}$ after treatment. The Akt phosphorylation level was lower in the cells receiving the combination treatment than in the cells treated with radiation or C225 alone.

Conclusions: These findings indicate that C225 sensitizes LS180 cells to ${ }^{125}$ I seed radiation. Growth inhibition is mediated by inducing apoptosis and not cell cycle arrest. Additionally, we confirmed that C225 impairs DNA repair by reducing the cellular level of the DNA-PKcs and Ku70 proteins. Furthermore, the inhibition of Akt signaling activation may be responsible for the C225-mediated radiosensitization.
\end{abstract}

Keywords: C225, Apoptosis, DNA repair, Y-H2AX, DNA-PK

\section{Background}

Colorectal cancer (CRC) is the third most common lethal disease, and it accounts for approximately one million new cancer cases and approximately $10 \%$ of all cancer deaths annually [1]. Preoperative radiochemotherapy administered concomitantly with 5-fluorouracil has become the standard of care in rectal cancer, especially in tumors of the lower and middle rectum [2]. Recently, high dose rate endorectal brachytherapy has emerged as an alternative neoadjuvant treatment for low-lying rectal cancer [3-5]. In our previous study, we found that brachytherapy with low dose 125 -iodine $\left({ }^{125} \mathrm{I}\right)$ seeds could serve as an effective salvage therapy for recurring rectal cancer [6].

Epidermal growth factor receptor (EGFR) is known to be overexpressed in a wide range of cancers, including ovarian, brain, breast, colorectal, kidney, and pancreatic

\footnotetext{
* Correspondence: junjiew920@sohu.com

'Cancer Center, Peking University Third Hospital, Beijing, China

Full list of author information is available at the end of the article
}

cancers [7]. Multiple lines of evidence indicate that EGFR is an important determinant of radioresponse and has a radioprotective function. Based on current evidence, EGFR-mediated radioprotection can be conceptually divided into three phases: (a) an immediate early phase that involves DNA repair, (b) suppression of DNA damage-induced apoptosis before and after cell cycle arrest, and (c) a tumor repopulation step that offers a proliferative advantage to tumors emerging from radiation-induced cell cycle arrest [8]. Based on the appreciation of the role of EGFR in cancer, several molecularly targeted agents such as gefitinib, erlotinib, and cetuximab (Erbitux, C225) have been developed to inhibit the activity of this receptor. Gefitinib and erlotinib are FDA-approved as single agents for advanced nonsmall cell lung cancer (NSCLC), and C225 has been approved for the treatment of advanced colon cancer in combination with cisplatin and for head and neck squamous cell carcinoma (HNSCC) in combination with radiation [7].

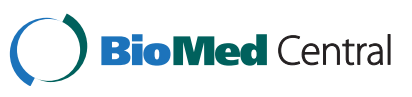

(c) 2013 Liu et al.; licensee BioMed Central Ltd. This is an Open Access article distributed under the terms of the Creative Commons Attribution License (http://creativecommons.org/licenses/by/2.0), which permits unrestricted use, distribution, and reproduction in any medium, provided the original work is properly cited. 
There are several compelling reasons to explore the efficacy of combined therapy of $\mathrm{C} 225$ with continuous low dose rate (CLDR) radiation. C225 commonly produces cytostatic effects that can prevent tumor cell repopulation during the fractionated course of radiation [9]. The short duration of time to deliver CLDR treatment represents a few doubling times for clonogenic cancer cells [10]. Thus, C225 and CLDR treatments administered together may have more cytostatic effects than either treatment alone. If $\mathrm{C} 225$ could also produce a cytotoxic effect and radiosensitization, its effect on reducing cell survival of in colorectal cancer cells can be further increased when combined with CLDR.

In the present study, we investigated the role of $\mathrm{C} 225$ in modulating the radioresponse of colorectal cancer cells to ${ }^{125} \mathrm{I}$ seed continuous low dose rate irradiation $\left({ }^{125} \mathrm{I}-\mathrm{CLDR}\right)$ in vitro. Clonogenic and proliferation assays revealed that $\mathrm{C} 225$ enhanced the antitumor effects of

${ }^{125}$ I-CLDR. While dissecting the mechanism underlying this radiosensitization, we observed that C225 administration increased ${ }^{125} \mathrm{I}$-CLDR-induced apoptosis and impaired the repair capacity of cellular DNA, but did not affect ${ }^{125}$ I-CLDR-induced cell cycle arrest. These effects of $\mathrm{C} 225$ on irradiation may have been mediated by its inhibition of Akt activation. In this study, we investigated the combined effect of C225 therapy and ${ }^{125}$ I-CLDR in the treatment of colorectal cancer.

\section{Results}

Sensitization of LS180 cells to radiation from ${ }^{125}$ I seeds by $\mathrm{C} 225$

To assess the radiation-enhancing effects of $\mathrm{C} 225$, the cells were exposed to CLDR from ${ }^{125}$ I seeds with and without concurrent treatment with $100 \mathrm{nM}$ of $\mathrm{C} 225$. Figure 1 shows the survival curves of in LS180 cells for treatment with radiation alone and in combination with C225. In our study, the survival fraction at $1 \mathrm{~Gy}, 2 \mathrm{~Gy}$, $4 \mathrm{~Gy}$ in $125 \mathrm{I}-\mathrm{CLDR}$ treated cells was $0.61 \pm 0.09,0.30 \pm$ $0.04,0.05 \pm 0.003$, and the corresponding rate in $\mathrm{C} 225+$ $125 \mathrm{I}-\mathrm{CLDR}$ group was $0.51 \pm 0.02,0.18 \pm 0.01,0.02 \pm 0.006$, respectively. We found there were significant differences concerning clonogenic survival between 125I-CLDR and C225 + 125I-CLDR groups when we used two-way ANOVA for data analysis. The sensitizer enhancement ratio (SER) was approximately 1.4, indicating that C225 increased the radiosensitivity of LS180 cells to radiation from ${ }^{125}$ I seeds. The radiobiological parameters of the LS180 cells are shown in Table 1.

\section{C225 promotes the radiation-induced inhibition of proliferation}

We used the MTS proliferation assay to investigate the growth-inhibitory effects of radiation and C225. As shown in Figure 2A, C225 treatment and radiotherapy

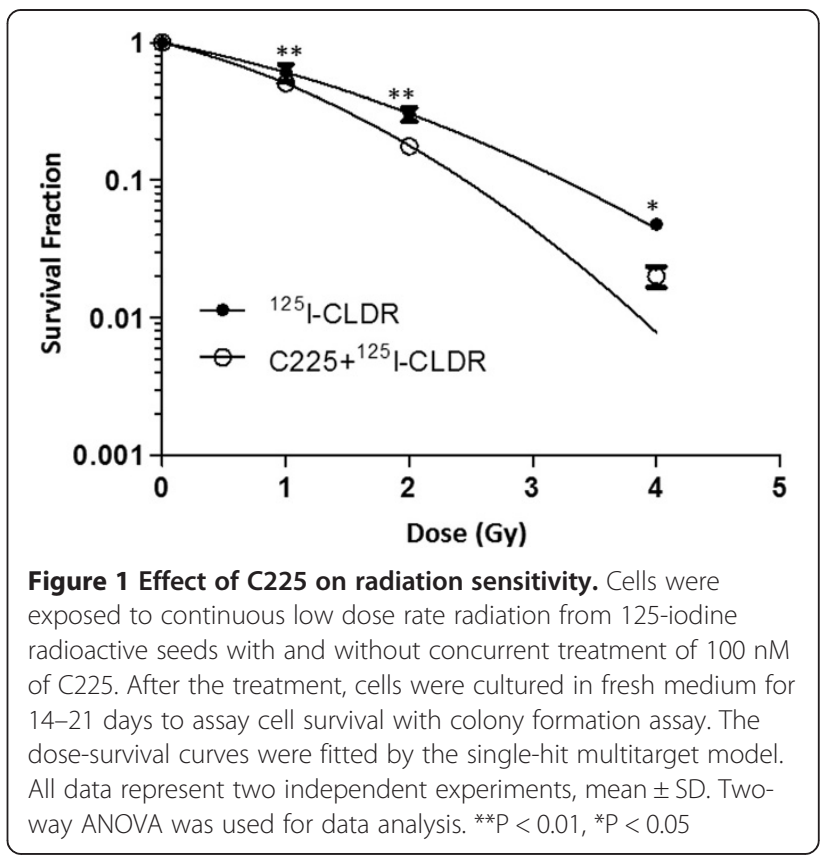

each significantly inhibited LS180 cell growth when used alone (72 h, Ctrl vs. C225, $\mathrm{t}=25.5, \mathrm{P}<0.001$; Ctrl vs. ${ }^{125}$ I-CLDR, $\left.\mathrm{t}=53.1, \mathrm{P}<0.001\right)$, but their combined inhibitory effect was greater than that produced by either treatment alone $\left(72 \mathrm{~h}, \mathrm{C} 225+{ }^{125} \mathrm{I}-\mathrm{CLDR}\right.$ vs. C225, $\mathrm{t}=$ 31.5, $\mathrm{P}<0.001 ; \mathrm{C} 225+{ }^{125} \mathrm{I}-\mathrm{CLDR}$ vs. ${ }^{125} \mathrm{I}-\mathrm{CLDR}, \mathrm{t}=3.7$, $\mathrm{P}<0.01)$. To further clarify the inhibitory effects of this combination, we detected the cell cycle distribution at indicated times after treatment. G2/M cell cycle arrest only appeared in ${ }^{125} \mathrm{I}-\mathrm{CLDR}$ and $\mathrm{C} 225+{ }^{125} \mathrm{I}$ CLDR treated group ( $0 \mathrm{~h}, \mathrm{Ctrl}$ vs. C225, $\mathrm{t}=2.4, \mathrm{P}>0.05$; Ctrl vs. ${ }^{125} \mathrm{I}-\mathrm{CLDR}, \mathrm{t}=3.5, \mathrm{P}<0.01$; Ctrl vs. $\mathrm{C} 225+{ }^{125} \mathrm{I}-$ CLDR, $\mathrm{t}=4.8, \mathrm{P}<0.001)$, but disappeared at $24 \mathrm{~h}$ after treatment (24 h, Ctrl vs. ${ }^{125} \mathrm{I}-\mathrm{CLDR}, \mathrm{t}=1.6, \mathrm{P}>0.05$; Ctrl vs. $\left.\mathrm{C} 225+{ }^{125} \mathrm{I}-\mathrm{CLDR}, \mathrm{t}=1.7, \mathrm{P}>0.05\right)$. G1 cell cycle arrest did not happen in all experiment groups $(48 \mathrm{~h}, \mathrm{Ctrl}$ vs. $\mathrm{C} 225, \mathrm{t}=1.5, \mathrm{P}>0.05$; Ctrl vs. ${ }^{125} \mathrm{I}-\mathrm{CLDR}, \mathrm{t}=0.5$, $\mathrm{P}>0.05$; Ctrl vs. C225 $\left.+{ }^{125} \mathrm{I}-\mathrm{CLDR}, \mathrm{t}=1.1, \mathrm{P}>0.05\right) . \mathrm{S}$ cell cycle decreased in three experiment groups within 48 hours after treatment $(48 \mathrm{~h}, \mathrm{Ctrl}$ vs. C225, $\mathrm{t}=5.1$,

Table 1 In vitro radiobiological parameters of LS180 cells (mean \pm SD)

\begin{tabular}{ccc}
\hline & ${ }^{125}$ I-CLDR & C225 $+{ }^{\mathbf{1 2 5} \text { I-CLDR }}$ \\
\hline$D_{0}(G y)$ & $1.20 \pm 0.15$ & $0.86 \pm 0.03$ \\
$D_{\mathrm{q}}(\mathrm{Gy})$ & $0.62 \pm 0.30$ & $0.54 \pm 0.06$ \\
$\mathrm{~N}$ & $1.67 \pm 0.31$ & $1.88 \pm 0.10$ \\
$\mathrm{SF}_{2}$ & $0.30 \pm 0.04$ & $0.18 \pm 0.01$
\end{tabular}

The values for $D_{0}, D_{q}$, and $N$ were determined using the single-hit multitarget model. $d=D_{0}\left({ }^{125} I-C L D R\right) / D_{0}\left(C 225+{ }^{125} I-C L D R\right) . D_{0}$, Mean inactivation dose; $D_{q}$, Quasi-threshold dose; N, extrapolation number; $\mathrm{SF}_{2}$, Survival fraction at 2 Gy. 


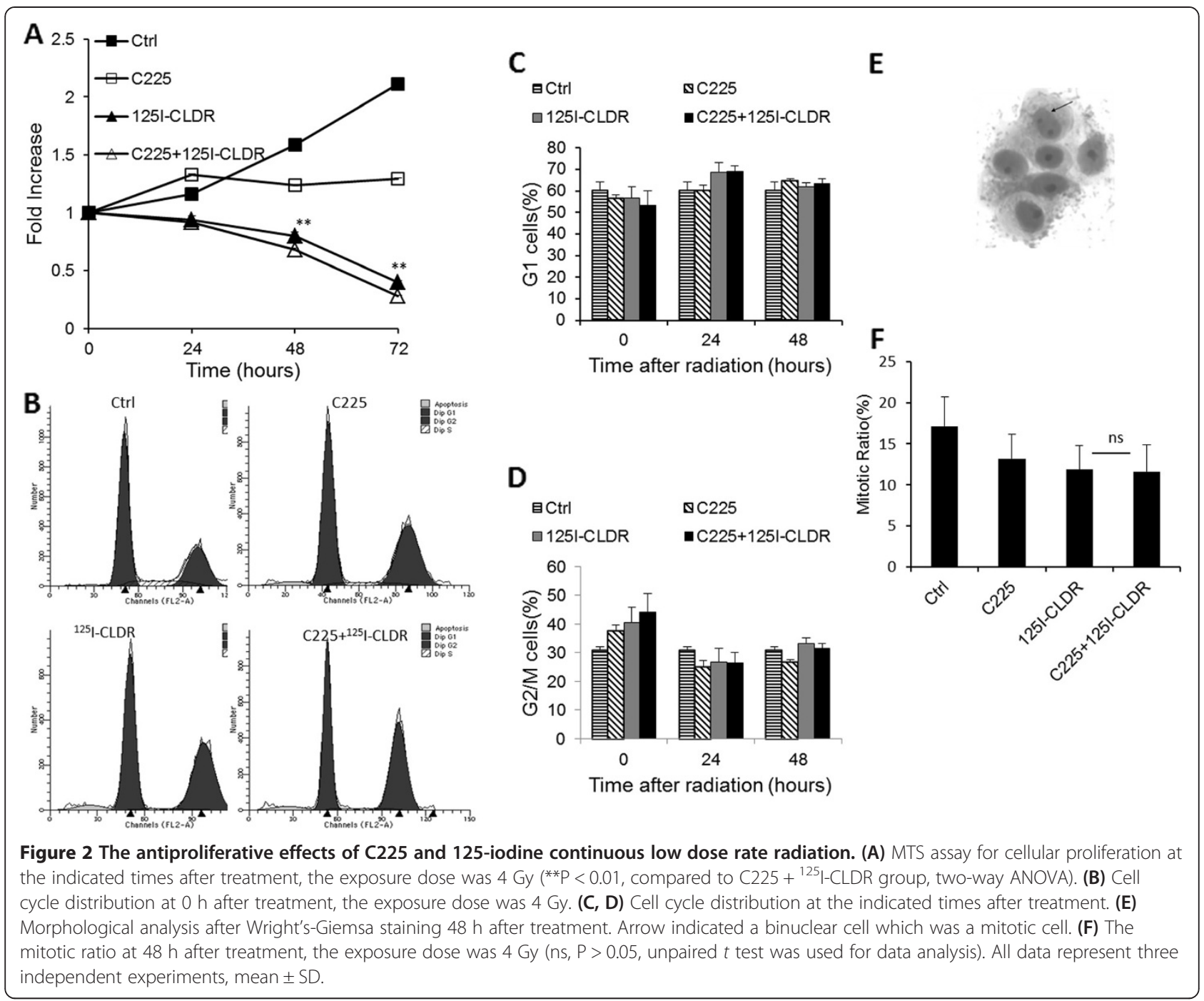

$\mathrm{P}<0.001$; Ctrl vs. ${ }^{125} \mathrm{I}-\mathrm{CLDR}, \mathrm{t}=11.2, \mathrm{P}<0.001$; Ctrl vs. $\left.\mathrm{C} 225+{ }^{125} \mathrm{I}-\mathrm{CLDR}, \mathrm{t}=11.3, \mathrm{P}<0.001\right)$. The cell cycle distribution between $\mathrm{C} 225+{ }^{125} \mathrm{I}$-CLDR and ${ }^{125} \mathrm{I}$-CLDR treated cells shew no significant differences within 48 hours after treatment (48 h, C225 $+{ }^{125}$ I-CLDR vs. ${ }^{125} \mathrm{I}-\mathrm{CLDR}, \mathrm{G} 1$, $\mathrm{t}=0.6, \mathrm{P}>0.05 ; \mathrm{S}, \mathrm{t}=0.1, \mathrm{P}>0.05 ; \mathrm{G} 2 / \mathrm{M}, \mathrm{t}=0.6, \mathrm{P}>0.05)$ (Figure 2B, C, D).

We further detected the mitotic ratio at $48 \mathrm{~h}$ after treatment in the four groups and found that there were no significant differences ( $48 \mathrm{~h}, \mathrm{Ctrl}$ vs. $\mathrm{C} 225, \mathrm{t}=1.2, \mathrm{P}=0.4$; Ctrl vs. ${ }^{125} \mathrm{I}-\mathrm{CLDR}, \mathrm{t}=1.6, \mathrm{P}=0.3$; Ctrl vs. C225 $+{ }^{125} \mathrm{I}-\mathrm{CLDR}$, $\mathrm{t}=1.6, \mathrm{P}=0.3$; unpaired $t$ test) (Figure $2 \mathrm{E}, \mathrm{F}$ ).

\section{C225 increases radiation-induced cellular apoptosis}

We then detected cell death by annexin V-FITC/PI assay. As shown in Figure 3, both $\mathrm{C} 225$ and radiation induced slight cellular apoptosis when administered alone (48 h, Ctrl vs. C225, t $=4.9, \mathrm{P}=0.008$; Ctrl vs. ${ }^{125} \mathrm{I}$ CLDR, $\mathrm{t}=4.4, \mathrm{P}=0.012$; unpaired $t$ test), and in the combined treatment, $\mathrm{C} 225$ increased radiation-induced apoptosis (48 h, Ctrl vs. C225 $+{ }^{125} \mathrm{I}-\mathrm{CLDR}, \mathrm{t}=24.9$, $\mathrm{P}<0.001 ; \mathrm{C} 225+{ }^{125} \mathrm{I}-\mathrm{CLDR}$ vs. ${ }^{125} \mathrm{I}-\mathrm{CLDR}, \mathrm{t}=6.6, \mathrm{P}=$ 0.003; unpaired $t$ test). Furthermore, the $\mathrm{Bax} / \mathrm{Bcl} 2$ ratio was increased by $\mathrm{C} 225$ and radiation either $(24 \mathrm{~h}, \mathrm{Ctrl}$ vs. $\mathrm{C} 225, \mathrm{t}=5.9, \mathrm{P}=0.03$; Ctrl vs. ${ }^{125} \mathrm{I}-\mathrm{CLDR}, \mathrm{t}=26.5$, $\mathrm{P}=0.0014$; unpaired $t$ test) and increased to highest level by the combined treatment $\left(24 \mathrm{~h}, \mathrm{Ctrl}\right.$ vs. C225 $+{ }^{125} \mathrm{I}$ CLDR, $\mathrm{t}=107.4, \mathrm{P}<0.001$; unpaired $t$ test). Thus, the combined treatment produced antiproliferative effects by inducing cellular apoptosis as a result of imbalance in the ratio of the pro-apoptotic protein Bax and the pro-survival protein $\mathrm{Bcl} 2$.

\section{C225 reduces the cellular DNA repair capacity}

Radiation plays a key role in cancer therapy due to its ability to directly induce DNA damage. In order to determine the cellular DNA damage and repair, immunofluorescence staining was used to determine the nuclear 


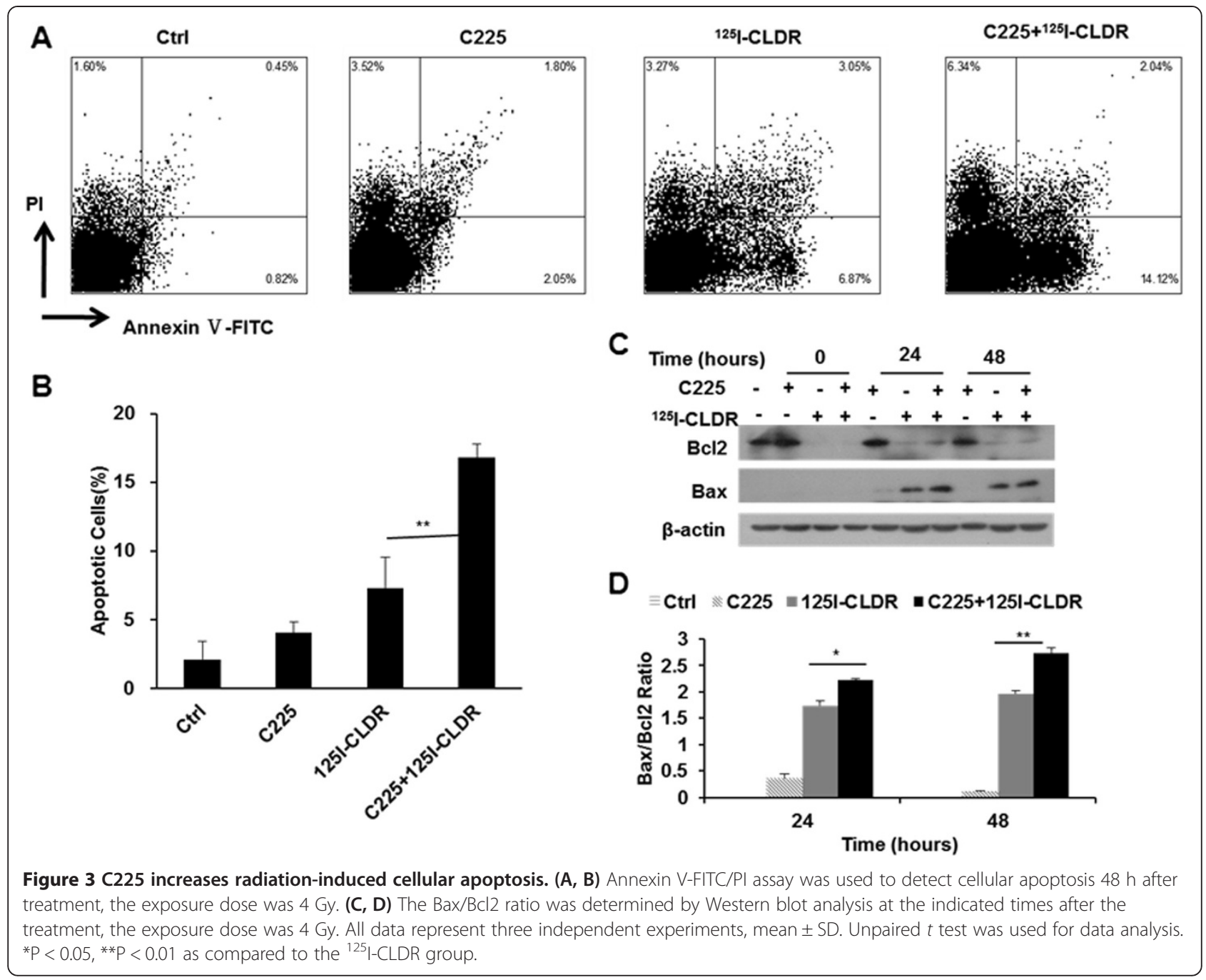

$\gamma$-H2AX foci $48 \mathrm{~h}$ after treatment. The results revealed a limited number of cells in the control group exhibiting $\gamma$-H2AX foci $(6.5 \pm 0.7 \%)$. However, cells receiving combined treatment $(59.1 \pm 2.2 \%)$ demonstrated a significant increase in the $\gamma$-H2AX focus-positive cells as compared to those treated with radiation $(48.5 \pm 0.1 \%)$ or $\mathrm{C} 225$ $(4.5 \pm 3.5 \%)$ alone. To determine whether DNA repair proteins were expressed, western blotting was performed using lysates from the cells that received the different treatment protocols. The expression levels of DNA-Pkcs (48 h, C225 + ${ }^{125}$ I-CLDR vs. ${ }^{125} \mathrm{I}-\mathrm{CLDR}, \mathrm{t}=5.7, \mathrm{P}=0.005$; unpaired $t$ test) and Ku70 (48 h, C225 $+{ }^{125}$ I-CLDR vs. ${ }^{125} \mathrm{I}-$ CLDR, $\mathrm{t}=6.6, \mathrm{P}=0.003$; unpaired $t$ test) proteins decreased with the combined treatment, suggesting that $\mathrm{C} 225$ reduced the cellular DNA repair capacity by reducing the DNA-PKcs and Ku70 protein levels.

\section{C225 inhibits Akt activation}

When the cancer cells overexpressing EGFR were exposed to radiation, the survival and proliferation mechanisms were predominantly activated through signaling via PI3KAkt and Ras-Erk. Western blot analysis was used to detect the activation of these two pathways. Our results revealed that the phosphorylation level of Akt was lower in the cells receiving the combined treatment $\left(0 \mathrm{~h}, \mathrm{C} 225+{ }^{125} \mathrm{I}-\mathrm{CLDR}\right.$ vs. $\mathrm{C} 225, \mathrm{t}=9.2, \mathrm{P}<0.001 ; \mathrm{C} 225+{ }^{125} \mathrm{I}-\mathrm{CLDR}$ vs. ${ }^{125} \mathrm{I}-$ CLDR, $\mathrm{t}=7.3, \mathrm{P}=0.0019$; unpaired $t$ test) than in those receiving either treatment alone $(0 \mathrm{~h}, \mathrm{Ctrl}$ vs. $\mathrm{C} 225, \mathrm{t}=2.8$, $\mathrm{P}=0.051$; Ctrl vs. ${ }^{125} \mathrm{I}-\mathrm{CLDR}, \mathrm{t}=5.3, \mathrm{P}=0.006$; unpaired $t$ test). However, there were no significant differences in the activation level of Erk between the different treatment groups.

\section{Discussion}

Preoperative external beam radiotherapy has been shown to increase pathological complete remission and reduce the probability of local recurrence; however, this mode of treatment is also associated with increased risk of therapyinduced side-effects and increased morbidity [3]. High dose rate brachytherapy has been found to be an alternative to 
external beam radiotherapy in rectal cancer $[3,4,11]$. Radiation induces an increase in the EGFR expression in cancer cells, and blockade of EGFR signaling sensitizes cells to the effects of radiation [12]. Anti-EGFR monoclonal antibody C225 has been approved for treating HNSCC in combination with radiation because of the synergistic effects of these two treatment approaches [13]. The application of radiosensitizers to sensitize cancer cells to radiation is a promising and emerging strategy. Here, we investigated the capacity of the anti-EGFR mAb C225 to modulate the radiosensitivity and inhibit cellular proliferation in human colorectal cancer cells.

Our results indicated that $\mathrm{C} 225$ enhanced the sensitivity of LS180 cells to ${ }^{125}$ I seed radiation (Figure 1). The relatively lower $D_{0}$ value suggested that cancer cells could be killed at reasonably lower doses of radiation when coupled with C225 (Table 1). Previous studies have suggested that the capacity of C225 to modulate cancer cell proliferation and cell cycle distribution might play a central role in its enhancement of radiosensitivity [14]. Our results demonstrated that continuous exposure to C225 inhibited LS180 cell proliferation, and this inhibitory effect was more significant when C225 was combined with radiation (Figure 2A). The growth inhibition of LS180 cells was mediated by apoptosis induction (Figure 3) rather than cell cycle arrest (Figure 2B, C, and $\mathrm{D})$. Moreover, mitotic ratio analysis revealed that combined treatment did not affect the mitotic index (Figure 2E and F).

We speculate that the enhancement of radiosensitivity by $\mathrm{C} 225$ is mediated through inhibiting DNA repair. Among all the radiation-induced damages, DNA doublestrand breaks (DSBs) are the greatest threat to cancer cells. In eukaryotic cells, DSBs are repaired primarily by non-homologous end-joining (NHEJ) and homologous recombination (HR) [15]. NHEJ is a faster and more efficient DSB repair pathway than HR [16], and is the dominant mechanism in mammalian cells. The proteins and enzymes of NHEJ include Ku70/80, DNA-PKcs, Artemis, XRCC4, and DNA ligase IV. $\gamma-\mathrm{H} 2 \mathrm{AX}$ foci form at any nascent DSB, and are first visible approximately $3 \mathrm{~min}$ post-irradiation by immunoflurorescence microscopy, after which they increase in size until approximately $30 \mathrm{~min}$ and then decrease in number with a half-life of several hours [17]. One $\gamma-\mathrm{H} 2 \mathrm{AX}$ focus correlates to one DSB, and one DSB remaining unrepaired in a cell can potentially result in cell death [18]. Recent findings by Banath et al. [19] suggested that the retained $\gamma-\mathrm{H} 2 \mathrm{AX}$ foci at 24 hours after treatment were lethal and those $\gamma$ H2AX focus-positive cells would subsequently lose clonogenicity. Our findings showed that the $\gamma$-H2AX focus-positive cell fraction was higher in the cells that received the combination therapy than those that received C225 or radiation alone (Figure 4A, B, and C).
Furthermore, the lowest levels of DNA-PKcs and Ku70 were found in the cells that received the combination therapy (Figure 4D, E, and F). Therefore, these findings indicate that $\mathrm{C} 225$ impairs DNA repair by reducing the cellular level of DNA-PKcs and Ku70.

Furthermore, we determined the biochemical processes responsible for the $\mathrm{C} 225$-mediated radiosensitization. An increasing body of data indicates that the PI3K/AKT- and Ras/Raf/MEK/ERK-mediated signaling pathways may govern EGFR-mediated radioresistance [20,21]. In our study, we found that C225 inhibited Akt activation and downregulated EGFR expression when combined with radiation, but did not exert any effects on Erk activation (Figure 5). The inhibition of PI3K-Akt signaling was associated with the downregulation of DNA-PKCS [20]. However, C225-treated cells exhibited EGFR upregulation, suggesting that the cells developed resistance to $\mathrm{C} 225$ [22]. Comfortingly, radiation from

${ }^{125}$ I downregulated the expression of EGFR protein, and the cells that received the combination treatment showed lower EGFR protein levels. Thus, C225 played opposite roles in the regulation of EGFR protein in cells treated with or without ${ }^{125}$ I radiation. However, the mechanisms underlying these opposing functions of $\mathrm{C} 225$ remain to be elucidated.

\section{Conclusions}

Our findings indicate that C225 sensitizes LS180 cells to ${ }^{125}$ I seed radiation. Growth inhibition was mediated by inducing apoptosis rather than cell cycle arrest. Additionally, we confirmed that C225 impaired DNA repair by reducing the cellular level of DNA-PKcs and Ku70 proteins. Furthermore, C225-mediated radiosensitization may be caused by the inhibition of activation of Akt signaling.

\section{Materials and methods \\ Cell culture}

The human colon carcinoma cell line LS180 was kindly provided by the Beijing Institute for Cancer Research. Cells were grown in RPMI-1640 supplemented with $20 \mathrm{mM}$ HEPES (pH 7.4), $100 \mathrm{IU} / \mathrm{mL}$ penicillin, $100 \mathrm{mg} /$ $\mathrm{mL}$ streptomycin, $4 \mathrm{mM}$ glutamine (Gibco, China), and 10\% heat-inactivated fetal bovine serum (FBS; Hangzhou Sijiqing Biological Engineering Materials Company, China) in a humidified atmosphere of $5 \% \mathrm{CO}_{2}$ at $37^{\circ} \mathrm{C}$.

\section{Radiation with ${ }^{125}$ I radioactive seeds and C225 treatment}

We used an in vitro ${ }^{125} \mathrm{I}$ seed radiation model that had been developed in our laboratory [23,24]. In this model, the exposure times for delivering doses of $1,2,4,6$, 8, and 10 Gy were 36, 73.7, 154.6, 245.8, 345.1, and 460.1 hours, respectively. $100 \mathrm{nM} \mathrm{C} 225$ was chosen to treat cells, and the $\mathrm{C} 225$ treatment was continuous and 


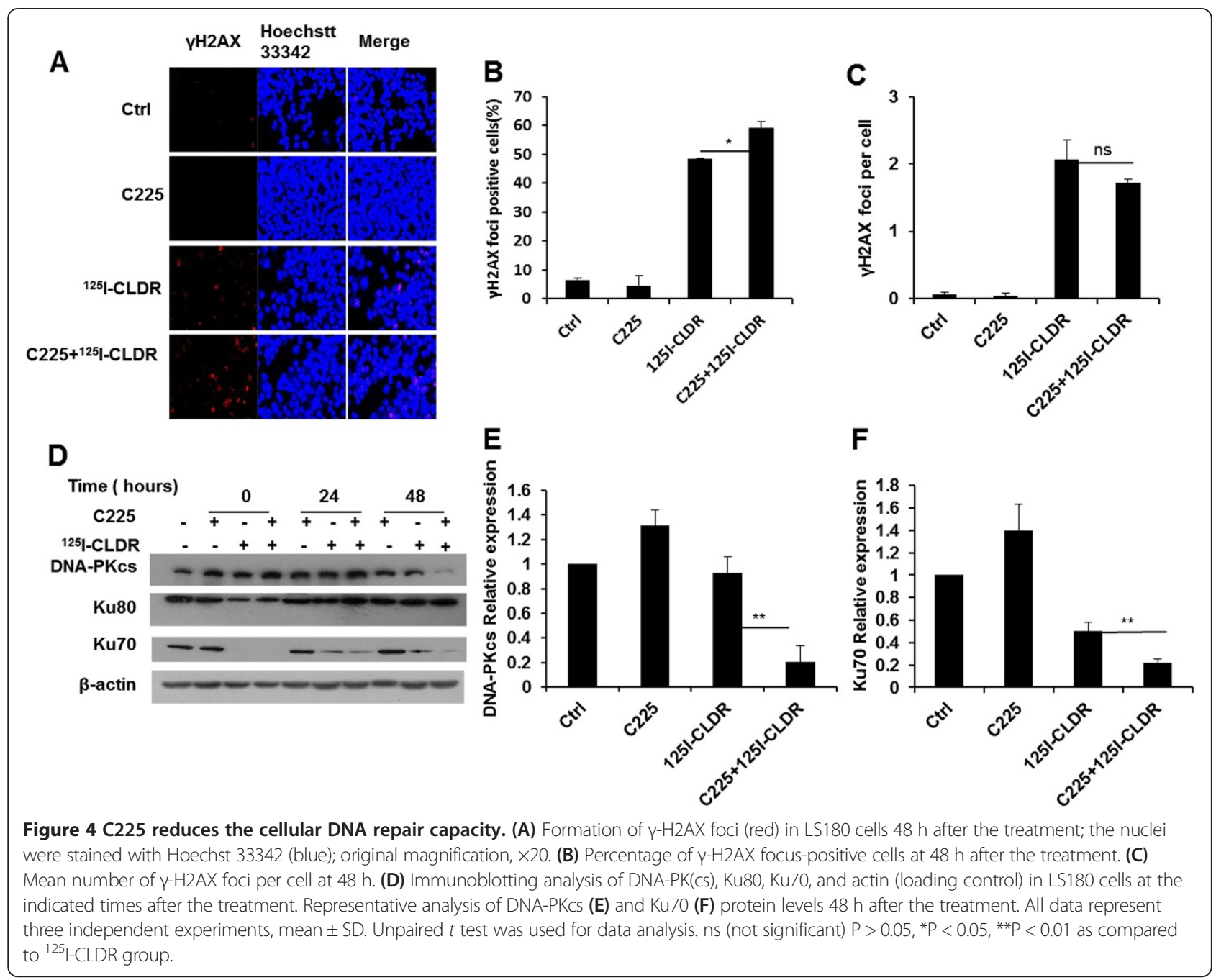

concurrent. For example, C225 $+{ }^{125}$ I-CLDR treated cells needs 7 days' continuous and concurrent C225 treatment when the exposure dose is $4 \mathrm{~Gy}$.

\section{Antibodies}

The human-mouse chimeric anti-EGFR monoclonal antibody (mAb) cetuximab $(\mathrm{C} 225,5 \mathrm{mg} / \mathrm{ml})$ was provided by ImClone Systems, Inc. (New York, NY, USA). The following primary antibodies were purchased from Cell Signaling Technology (Beverly, MA, USA): rabbit monoclonal anti- $\gamma-\mathrm{H} 2 \mathrm{AX}$, anti-EGFR, antiErk1/2, anti-phospho-Erk1/2, anti-Akt, anti-phosphoSer473 Akt, anti-Bcl-2, anti-Bax, anti-Ku70, anti-Ku80, and anti-DNA-PKcs antibodies. The following secondary antibodies were obtained for use in this study: Alexa Fluor 546 goat anti-rabbit IgG $(\mathrm{H}+\mathrm{L})$ (Invitrogen, Carlsbad, CA, USA) and horseradish peroxidase (HRP)conjugated anti-rabbit IgG.

\section{Colony formation assay}

After treatment, the cells were trypsinized to generate a single cell suspension, and a specific number of trypan blue-negative cells were seeded into each well of a six-well tissue culture plate. After the plates were incubated for 14-21 days, colonies were stained with Wright's-Giemsa solution and manually counted. Colonies containing $>50$ cells were scored, and three replicate dishes containing 10-150 colonies per dish were counted for each treatment.

\section{Cell proliferation assay}

After treatment, the cells were trypsinized to generate a single cell suspension, plated at $5 \times 10^{3}$ cells/well in 96-well plates containing $200 \mu \mathrm{L}$ growth medium, and allowed to attach for $24 \mathrm{~h}$. At harvest, the medium was removed from the appropriate wells, replaced with $100 \mu \mathrm{L}$ MTS solution (2.5 mg/mL, Beijing PreGene Biotechnology Company, Ltd. 

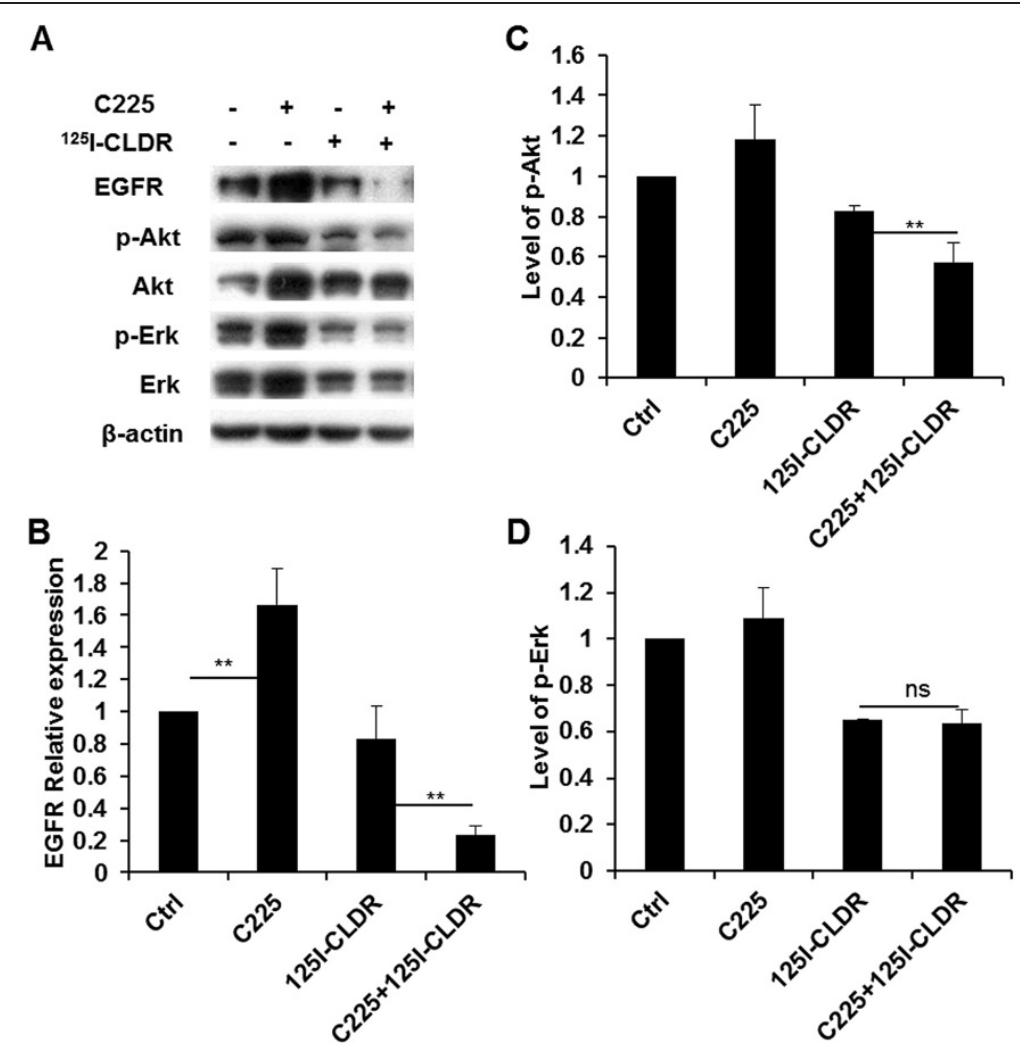

Figure 5 C225 inhibits the activation of Akt and Erk when combined with radiation. (A) Immunoblotting of some proteins involving in EGFR signaling pathways at the end of treatment $(0 \mathrm{~h})$, the exposure dose was $4 \mathrm{~Gy}$. Cells were lysed immediately after treatment. Representative analysis of the protein levels of EGFR (B), phosphorylated Akt (C), and phosphorylated Erk (D). All data represent three independent experiments, mean $\pm \mathrm{SD}$. Unpaired $t$ test was used for data analysis.

Beijing, China), and incubated for 2 hours at $37^{\circ} \mathrm{C}$. After incubation, the plate was analyzed on a plate reader by SoftMax program (Molecular Devices Corp., Menlo Park, CA, USA).

\section{Cell cycle analysis}

The cells were harvested by trypsinization at the indicated times after treatment, washed with ice-cold phosphatebuffered saline (PBS), fixed in 75\% ethanol, and stored at $-20^{\circ} \mathrm{C}$. Prior to analysis, $1 \mu \mathrm{g} / \mathrm{mL}$ propidium iodide (PI) and $1 \mathrm{mg} / \mathrm{mL}$ RNAse A were used to label the DNA. Flow cytometry (FACSCalibur, BD Biosciences, San Jose, CA, USA) was used for cell cycle analysis.

\section{Mitotic ratio analysis}

Cells were harvested by trypsinization at $48 \mathrm{~h}$ after treatment, treated with ice-cold $0.56 \% \mathrm{KCl}$ for $3 \mathrm{mi}-$ nutes, pelleted by centrifugation for $10 \mathrm{~min}$ at $400 \times \mathrm{g}$, resuspended in Carnoy's fluid (methanol:glacial acetic acid $=3: 1$ ), spread on a slide, air dried, and stained with Wright's-Giemsa solution. The binuclear cells were observed under a light microscope.

\section{Apoptotic cell death}

The Annexin V-FITC/PI assay (Beijing Zoman Biotechnology Company, Ltd. Beijing, China) was performed according to the manufacturer's instructions. Briefly, $5 \times 10^{5}$ cells were added to $200 \mu \mathrm{L}$ of staining solution containing $195 \mu \mathrm{L}$ of apoptosis buffer and $5 \mu \mathrm{L}$ Annexin V-FITC. Samples were incubated in the dark at room temperature or $4^{\circ} \mathrm{C}$ for 30 minutes, after which $300 \mu \mathrm{L}$ of apoptosis buffer was added. Five minutes before analysis, $10 \mu \mathrm{L}$ PI was added for chromatin staining. The samples were then analyzed using a Coulter Epics XL cytometer.

\section{Immunofluorescence staining for $\mathrm{Y}-\mathrm{H} 2 \mathrm{AX}$ foci}

The cells were harvested by trypsinization $48 \mathrm{~h}$ after the treatment, treated with ice-cold $0.56 \% \mathrm{KCl}$ for 3 minutes, and pelleted by centrifugation for $10 \mathrm{~min}$ at $800 \mathrm{rpm}$. The pellets were then resuspended in Carnoy's fluid (methanol:glacial acetic acid $=3: 1$ ), spread on a slide, air dried, and rinsed with 95\% ethanol and purified water. Cells were permeabilized in $0.3 \%$ Triton X-100 at room temperature for $15 \mathrm{~min}$, and washed three times for 10 min each in PBS. The cells were then blocked with a solution of 1\% BSA, 0.3\% Triton X-100, and PBS (room temperature) for $2 \mathrm{~h}$, and washed three times for $10 \mathrm{~min}$ 
each in PBS. The samples were then incubated with primary monoclonal anti- $\gamma-\mathrm{H} 2 \mathrm{AX}$ antibody (1:400) in $1 \%$ BSA, $0.3 \%$ Triton X-100, and PBS overnight at $4{ }^{\circ} \mathrm{C}$, washed in PBS three times for $10 \mathrm{~min}$ each, and incubated with Alexa Fluor 546-conjugated secondary antibodies (1:200) for $1 \mathrm{~h}$ at room temperature. Thereafter, the antibodies were washed in PBS four times for 10 min, and counterstained with Hoechst 33342. The cells were examined on a Zeiss LSM510 confocal scanning microscope. In a single experiment, cells were counted by eyes in the stored images (original magnification, $\times 40$ ) until at least 100 cells or 100 foci were registered.

\section{Western blot analysis}

The treated cells were lysed with Tween-20 lysis buffer (50 mM HEPES (pH 7.4), $150 \mathrm{mM} \mathrm{NaCl}, 0.1 \%$ Tween-20, 10\% glycerol, 2.5 mM EGTA, 1 mM EDTA, 1 mM DTT, and $1 \mathrm{mM}$ PMSF). Equal amounts of protein were analyzed by sodium dodecyl sulfate-polyacrylamide gel electrophoresis (SDS-PAGE). Thereafter, the proteins were transferred to nitrocellulose membranes and analyzed by specific primary antibodies. Proteins were detected with enhanced chemiluminescence after incubation with horseradish peroxidase-conjugated secondary antibodies.

\section{Statistical analysis}

Data were expressed as mean \pm SD. Every experiment was repeated at least twice. Statistical analysis was performed using GraphPad Prism software version 5.0 (GraphPad, San Diego, CA, USA). Student's $t$ test and ANOVA were used when appropriate. Differences were considered significant if $\mathrm{P}<0.05$

\section{Competing interests}

The authors declare that they have no competing interests.

\section{Authors' contributions}

LJ carried out all the experiments and drafted the manuscript. QA, WH and LJN participated in the cell culture. WJJ and ZY participated in the experiment design and drafted the manuscript. All authors read and approved the final manuscript.

\section{Acknowledgements}

The authors wish to thank Jing WANG and Jianxia PENG for their expert technical assistance and Qinghuan LI for her excellent laboratory management. We thank all the students from Transplantation Biology Research Division for their kind assistance. The work was supported by a grant from the National Natural Science Foundation of China (No. 81071834).

\section{Author details}

${ }^{1}$ Cancer Center, Peking University Third Hospital, Beijing, China. ${ }^{2}$ Transplantation Biology Research Division, State Key Laboratory of Biomembrane and Membrane Biotechnology, Institute of Zoology, Chinese Academy of Sciences, Beijing, China.

Received: 20 May 2013 Accepted: 17 September 2013 Published: 23 September 2013

\section{References}

1. Kamangar F, Dores GM, Anderson WF: Patterns of cancer incidence, mortality, and prevalence across five continents: defining priorities to reduce cancer disparities in different geographic regions of the world. J Clin Oncol 2006, 24(14):2137-2150

2. Velenik V, Oblak I, Anderluh F: Long-term results from a randomized phase II trial of neoadjuvant combined-modality therapy for locally advanced rectal cancer. Radiat Oncol 2010, 5:88.

3. Smith JA, Wild AT, Singhi A, et al: Clinicopathologic comparison of highdose-rate endorectal brachytherapy versus conventional chemoradiotherapy in the neoadjuvant setting for resectable stages II and III Low rectal cancer. Int I Surg Oncol 2012, 2012:406568.

4. Vuong T, Devic S, Podgorsak E: High dose rate endorectal brachytherapy as a neoadjuvant treatment for patients with resectable rectal cancer. Clin Oncol (R Coll Radiol) 2007, 19(9):701-705.

5. Sun Myint A, Mukhopadhyay T, Ramani VS, et al: Can increasing the dose of radiation by HDR brachytherapy boost following pre operative chemoradiotherapy for advanced rectal cancer improve surgical outcomes? Colorectal Dis 2010, 12(Suppl 2):30-36.

6. Wang JJ, Yuan HS, Li JN, et al: Interstitial permanent implantation of I-125 seeds as salvage therapy for re-recurrent rectal carcinoma. Int $J$ Colorectal Dis 2009, 24(4):391-399.

7. Meyn RE, Munshi A, Haymach JV, et al: Receptor signaling as a regulatory mechanism of DNA repair. Radiother Oncol 2009, 92(3):316-322.

8. Chen DJ, Nirodi CS: The epidermal growth factor receptor: a role in repair of radiation-induced DNA damage. Clin Cancer Res 2007, 13(22 Pt 1):6555-6560.

9. Nyati MK, Morgan MA, Feng FY, et al: Integration of EGFR inhibitors with radiochemotherapy. Nat Rev Cancer 2006, 6(11):876-885.

10. Dale RG, Jones B: The clinical radiobiology of brachytherapy. Br J Radiol 1998, 71(845):465-483.

11. Kolotas C, Roddiger S, Strassmann G, et al: Palliative interstitial HDR brachytherapy for recurrent rectal cancer, implantation techniques and results. Strahlenther Onkol 2003, 179(7):458-463.

12. Liang $K$, Ang KK, Milas $L$, et al: The epidermal growth factor receptor mediates radioresistance. Int J Radiat Oncol Biol Phys 2003, 57(1):246-254

13. Bonner JA, Harari PM, Giralt J, et al: Radiotherapy plus cetuximab for squamous-cell carcinoma of the head and neck. N Engl J Med 2006, 354(6):567-578.

14. Huang SM, Bock JM, Harari PM: Epidermal growth factor receptor blockade with C225 modulates proliferation, apoptosis, and radiosensitivity in squamous cell carcinomas of the head and neck. Cancer Res 1999, 59(8):1935-1940.

15. Shrivastav M, De Haro LP, Nickoloff JA: Regulation of DNA double-strand break repair pathway choice. Cell Res 2008, 18(1):134-147.

16. Mao Z, Bozzella M, Seluanov A, et al: Comparison of nonhomologous end joining and homologous recombination in human cells. DNA Repair (Amst) 2008, 7(10):1765-1771.

17. Sedelnikova OA, Pilch DR, Redon C, et al: Histone H2AX in DNA damage and repair. Cancer Biol Ther 2003, 2(3):233-235.

18. Takahashi A, Ohnishi T: Does gammaH2AX foci formation depend on the presence of DNA double strand breaks? Cancer Lett 2005, 229(2):171-179.

19. Banath JP, Klokov D, MacPhail SH, et al: Residual gammaH2AX foci as an indication of lethal DNA lesions. BMC Cancer 2010, 10:4

20. Choi EJ, Ryu YK, Kim SY, et al: Targeting epidermal growth factor receptorassociated signaling pathways in non-small cell lung cancer cells: implication in radiation response. Mol Cancer Res 2010, 8(7):1027-1036.

21. Gupta AK, McKenna WG, Weber CN, et al: Local recurrence in head and neck cancer: relationship to radiation resistance and signal transduction. Clin Cancer Res 2002, 8(3):885-892.

22. Harari PM, Wheeler DL, Grandis JR: Molecular target approaches in head and neck cancer: epidermal growth factor receptor and beyond. Semin Radiat Oncol 2009, 19(1):63-68.

23. Zhuang $H Q$, Wang JJ, Liao AY, et al: The biological effect of $125 \mathrm{I}$ seed continuous low dose rate irradiation in CL187 cells. J Exp Clin Cancer Res 2009, 28:12.

24. Wang J, Wang J, Liao A, et al: The direct biologic effects of radioactive 125 seeds on pancreatic cancer cells PANC-1, at continuous low-dose rates. Cancer Biother Radiopharm 2009, 24(4):409-416.

doi:10.1186/1748-717X-8-219

Cite this article as: Liu et al.: Combined effects of C225 and 125-iodine seed radiation on colorectal cancer cells. Radiation Oncology 2013 8:219. 